Advance Journal of Food Science and Technology 16(SPL): 307-312, 2018

DOI:10.19026/ajfst.16.5972

ISSN: 2042-4868; e-ISSN: 2042-4876

(C) 2018 Maxwell Scientific Publication Corp.

Submitted: September 29, $2017 \quad$ Accepted: January 10, $2018 \quad$ Published: November 10, 2018

\title{
Research Article \\ Contamination by Pathogenic Microorganisms in Water used for Agricultural Irrigation on the Sabana de Bogotá, Colombia
}

\author{
Argüello Heliodoro and Bustos-López Martha C. \\ Universidad Nacional de Colombia, Calle 45 Cra 30 Bogotá, Colombia
}

\begin{abstract}
The aim of this study was to evaluate the microbiological quality of water used to irrigate food crops, which can lead to the spread of certain microorganism, such as Escherichia coli, which poses a high risk of contamination for food, especially food consumed as fresh vegetables and milk, making it important to monitor the hygienic state of water based on the detection of "indicator" bacteria, which are normally only present in human and animal intestines, such as coliforms, which have been accepted worldwide as a unfailing parameter. To evaluate the water quality, the coliforms present in the water used for agricultural irrigation on the Sabana de Bogotá were quantified in the La Ramada irrigation district. Water samples were taken at ten agricultural irrigation points in municipalities around Bogotá. The methodology for the analysis included the technique that uses serial dilutions of samples in a specific culture media. In the different sampled sites where the water quality used for irrigation was evaluated, the total and fecal coliforms values were higher in CFU than the established limits (Decree 1594 of 1984) and values were found in some samples that were higher than $1 \times 10^{6} \mathrm{CFU} 100 / \mathrm{mL}$ for total coliforms and $1 \times 10^{5}$ CFU $100 / \mathrm{mL}$ for fecal coliforms. This study indicated that, with the current conditions of some water sources on the Sabana de Bogotá, there is an inherent source of contamination, creating an obstacle for agricultural irrigation and a microbiological risk for consumers.
\end{abstract}

Keywords: Escherichia coli, irrigation, microbiological risk, wastewater, water reuse

\section{INTRODUCTION}

The use of contaminated water for agricultural irrigation may lead to the spread of certain microorganisms, such as pathogenic Escherichia coli strains. Even with small amounts of these organisms, water can cause serious illnesses in humans. This is why the current conditions of some water sources on the Sabana de Bogotá may be an inherent source of contamination of products or a propagator of pathogenic microorganisms. On the other hand, when the type of irrigation involves the direct contact of water with the edible part of plants, there is a risk of contaminating the product if the water is not of the highest quality (Bustos et al., 2004).

The consumption of raw vegetables has been associated with numerous cases of disease outbreaks by pathogenic microorganisms. E. Coli has been linked to outbreaks of food-borne infections from vegetables and salads (Castro-Ibáñez et al., 2015; Holvoet et al., 2015). Fresh vegetables harbor a diverse population of microorganisms, with frequent amounts of $1 \times 10^{5}-1 \times 10^{7}$ $\mathrm{CFU} / \mathrm{g}$. Between $80-90 \%$ of bacteria are gram negative rods, with predominating species of Pseudomonas, Enterobacter or Erwinia. The transmission of pathogenic bacteria can occur by direct contamination with animal feces, the use of manure as fertilizer, residual water, or the use of contaminated water for irrigation (Acevedo et al., 2001).

The contribution of irrigation water to the contamination of products and foodborne diseases has been shown worldwide and the incidence of these pathogens in vegetables can be high in developing countries (Allende and Monaghan, 2015; Pachepsky et al., 2011; Steele and Odumeru, 2004)

Soto et al. (2016) reviewed the literature on foodborne diseases in Colombia related to bacteria for the years 2010-2013 and found reports related to the presence of Salmonella spp. and E. Coli in raw salads and Listeria monocytogenes in vegetables, but they emphasized that the reports are only on the products and not the production chain, where it is important to evaluate the risk.

In Colombia, Decree 1594 of 1984 from the Ministry of Agriculture regulates the use of water, including for agriculture, i.e., irrigation of crops and

Corresponding Author: Argüello Heliodoro, Universidad Nacional de Colombia, Calle 45 Cra 30 Bogotá, Colombia, Tel.: 57 3165000 ext 19083

This work is licensed under a Creative Commons Attribution 4.0 International License (URL: http://creativecommons.org/licenses/by/4.0/). 
other related or complementary activities. It establishes the admissible criteria for the destination of the resource (Chapter IV, Article 40) for the microbiological parameters and is still in force although resolution 1207 was issued in 2014, establishing the disposal of treated wastewater, which excludes directconsumption crops. However, $73 \%$ of the water used for irrigation is raw wastewater, without treatment, diluted with surface water, as in several Latin American countries (Silva et al., 2008), which represents a risk to public health since, in addition to bacteria, it carries surviving parasites, as indicated by the studies of Fonseca et al. (2016), who showed the first report in Colombia for the prevalence of Entamoeba moshkovski, a protozoan in raw wastewater used for agriculture, whose the pathogenic potential could be a health risk for the people exposed to this water.

The La Ramada irrigation district is in the middle basin of the Bogotá river in the Department of Cundinamarca, which contains 5,550 Ha (CAR, 2007) and uses this river as its supply, which receives raw wastewater discharge from the surrounding municipalities, so the quality of the water is affected, as seen in other areas on the Sabana de Bogotá, affecting crops that are mainly marketed in Bogotá.

Therefore, this study aimed to evaluate the presence of total coliforms, E. coli and Coliphages in the water used for irrigation on the Sabana de Bogotá. To achieve that, sampling of irrigation water was done in a representative area in the irrigation district. The results obtained in this study demonstrated that monitoring these indicators can be a useful tool for tracking and controlling the pollution levels of this irrigation district.

\section{MATERIALS AND METHODS}

Sampling was carried out in ten points of the $\mathrm{La}$ Ramada irrigation district, located in the western part of Bogotá. This district covers approximately 5000 ha, most of them dedicated to dairy farming and the production of fresh vegetables and flowers. In order to determine possible changes in the quality of the water used for irrigation over time, two seasonal periods were included in this study: during the months of March to May of 2003 in dry weather and November of 2014 and 2015 , in the rainy season. Spot sampling was carried out on 10 different sites along the irrigation district, taking $250 \mathrm{~mL}$ samples of water in sterilized containers and keeping them at $4{ }^{\circ} \mathrm{C}$ until analysis in the laboratory within $24 \mathrm{~h}$ (APHA, 2012).

The method used for the microbiological analysis of the collected waters was membrane filtration, consisting of passing the water sample through a microporous membrane filter with a pore size of $0.45 \mu$, assembling a vacuum system to retain bacterial cells so that they were homogeneously distributed in the filter, removing the filter from the filtration unit and placing it in the Chromocult culture medium and observing the simultaneous detection of total coliforms and E. coli. This type of culture medium uses enzymatic substrates which are widely used in the study of metabolic pathways in microorganisms, since they detect the presence of microorganisms in different types of samples, as well as enumerating and identifying them.

To obtain the Coliphages, the EPA1602 method was used with a bacterial culture that was prepared and incubated for $18-20 \mathrm{~h}$ at $36 \pm 1{ }^{\circ} \mathrm{C}$. From this culture, an aliquot was transferred to a fresh Trypticase Soy Broth and incubated for $4 \mathrm{~h}$ or until it reached an Optical Density (OD) of $0.1-0.5 .100 \mathrm{~mL}$ of $1.2 \%$ Trypticase Soy Agar prepared with $0.5 \mathrm{~mL}$ of magnesium chloride, $10 \mathrm{~mL}$ of the E. coli culture and $100 \mathrm{~mL}$ of the water sample. The mixture was homogenized and dispensed in 8 to 10 Petri dishes. The boxes were incubated at $36 \pm 1^{\circ} \mathrm{C}$ for $16-24 \mathrm{~h}$. The lysis plates were counted and the results were reported as Plaque Forming Units (PFU) /100 mL.

For the water chemical analysis, the water samples were analyzed according to standard methods (APHA, 2012). The measured parameters were: $\mathrm{pH}(\mathrm{pH}$ meter mod). Basic, WTW; electrical conductivity (ECw; $\mu \mathrm{S} / \mathrm{cm}$ ) (Conductivity Meter WTW); BOD5 (mg/L) (OD Sensor WTW); COD $(\mathrm{mg} / \mathrm{L})$ (Thermo-reactor MERCK) and Kjeldahl total nitrogen $\left(\mathrm{NH}_{4}{ }^{+}-\mathrm{N} ; \mathrm{mg} / \mathrm{L}\right)$.

\section{RESULTS AND DISCUSSION}

The geometric mean for each microbiological indicator during the 2003 sampling period are shown in Table 1 for the different stations. As can be observed, the highest microbial counts were found in the stations: San Jose Canal, Mosquera Canal, San Jose Los Pinos Canal and Bogotá-Tobacco River, with total coliform values of $1.64 \times 10^{8}, \quad 4.78 \times 10^{7}$ and $7.32 \times 10^{7}$, respectively. The fecal coliform count in the above stations varied between $10^{6}$ and $10^{7} \mathrm{CFU} / 100 \mathrm{~mL}$.

The water in those stations receive direct discharges of wastewater from rural homes, which could explain the higher results.

The Tres Esquinas station is located in a natural wetland, that has a self-depuration capacity to improve the water quality and it could explain the fact that the lowest values for all of the microbiological parameters were found at this station. In the same place, the fecal coliform value was six times lower than that found in the San Jose Canal, Mosquera variant.

In the stations Tres Esquinas, Tabaco, BogotáTabaco River and Tibaitata the count of fecal coliforms was always one order of magnitude higher than the Enterococcus, but, in the other stations, the difference between the values of these two indicators was greater, with fecal coliforms that were two orders of magnitude higher than the Enterococcus. In those stations where the presence of Coliphages was quantified, the value 
Adv. J. Food Sci. Technol., 16(SPL): 307-312, 2018

Table 1: Microorganism content, mean of ten samples, of the La Ramada irrigation district water (Bustos et al., 2004)

\begin{tabular}{|c|c|c|c|c|c|}
\hline Station* & $\begin{array}{l}\text { Total Colif. } \\
\text { CFU/100 mL }\end{array}$ & $\begin{array}{l}\text { Fecal Colif. } \\
\text { CFU/100 mL }\end{array}$ & $\begin{array}{l}\text { Enterococcus } \\
\text { CFU/100 mL }\end{array}$ & $\begin{array}{l}\text { Coliphages } \\
\text { CFU/100 mL }\end{array}$ & Salmonella \\
\hline 1 & $2.61 \times 10^{6}$ & $2.07 \times 10^{5}$ & $3.60 \times 10^{3}$ & $2.01 \times 10^{4}$ & $(-)$ \\
\hline 2 & $3.11 \times 10^{4}$ & $6.39 \times 10^{2}$ & $5.94 \times 10^{1}$ & & $(-)$ \\
\hline 3 & $4.64 \times 10^{5}$ & $3.04 \times 10^{4}$ & $4.41 \times 10^{2}$ & $4.13 \times 10^{3}$ & $(-)$ \\
\hline 4 & $7.42 \times 10^{5}$ & $1.20 \times 10^{4}$ & $1.29 \times 10^{2}$ & & $(++)$ \\
\hline 5 & $1.13 \times 10^{5}$ & $1.02 \times 10^{3}$ & $1.58 \times 10^{2}$ & & $(-)$ \\
\hline 6 & $4.33 \times 10^{5}$ & $4.53 \times 10^{4}$ & $4.38 \times 10^{2}$ & & $(-)$ \\
\hline 7 & $1.64 \times 10^{8}$ & $1.84 \times 10^{7}$ & $1.90 \times 10^{5}$ & $1.20 \times 10^{6}$ & $(-)$ \\
\hline 8 & $4.78 \times 10^{7}$ & $5.42 \times 10^{6}$ & $5.43 \times 10^{4}$ & $3.72 \times 10^{5}$ & $(-)$ \\
\hline 9 & $1.47 \times 10^{5}$ & $3.38 \times 10^{3}$ & $4.96 \times 10^{2}$ & & $(-)$ \\
\hline 10 & $7.32 \times 10^{7}$ & $8.29 \times 10^{6}$ & $1.78 \times 10^{5}$ & $3.70 \times 10^{5}$ & $(-)$ \\
\hline
\end{tabular}

Table 2: Microorganism content in the waste of the La Ramada irrigation district in 2014 and 2015

\begin{tabular}{lllll}
\hline Station* & Total Colif. & Fecal Colif. & Total Colif. & Fecal Colif. \\
CFU/100 mL & CFU/100 mL & 2014 & 2015 & 2015 \\
2 & 2014 & $6.0 \times 10^{6}$ & $7.0 \times 10^{5}$ & $1.6 \times 10^{8}$ \\
3 & $1.1 \times 10^{7}$ & $7.0 \times 10^{1}$ & $1.5 \times 10^{7}$ & - \\
4 & $1.3 \times 10^{3}$ & $6.0 \times 10^{6}$ & $2.1 \times 10^{9}$ & $3.1 \times 10^{7}$ \\
5 & $1.1 \times 10^{7}$ & $6.0 \times 10^{3}$ & $2.5 \times 10^{5}$ & $3.4 \times 10^{6}$ \\
6 & $2.2 \times 10^{5}$ & $2.5 \times 10^{4}$ & $1.0 \times 10^{7}$ & $1.4 \times 10^{8}$ \\
7 & $4.8 \times 10^{4}$ & $4.5 \times 10^{3}$ & $8.3 \times 10^{8}$ & $2.0 \times 10^{3}$ \\
8 & $9.3 \times 10^{3}$ & $5.0 \times 10^{3}$ & & $1.0 \times 10^{7}$ \\
*2: Ciénaga funza tres esquinas entrance; 3: canal B-diamante; 4: Ciénaga exit funza; 5: Canal tibaitata; 6: Canal sena; 7: Canal san josé
\end{tabular}

was very similar to the Enterococcus count. Counting Coliphages is important because they are an alternative to bacterial indicators of water contamination since they are indicators of fecal contamination and the possible presence of enteric transmission viruses, such as infectious hepatitis (Hepatitis A), Norovirus, or other Enterovirus, so, currently, the detection of Coliphages is considered an indicator of water quality.

As can be observed, the count of total and fecal coliforms at the Chicú Station, with values of $1 \times 10^{6}$ and $1 \times 10^{5}$, respectively, decreased by approximately two logarithmic units when arriving at the Cienaga Tres Esquinas and stayed more or less between $1 \times 10^{5}$ and $1 \times 10^{4}$ in the Diamante, Sena, Tibaitata and Funza canals. The count rose drastically to values of $1 \times 10^{8}$ and $1 \times 10^{7}$ for total and fecal coliforms in the San José Canal when the wastewaters of Mosquera entered it and again decreased en route to the Los Pinos and Tobacco Canal, down to values of $1 \times 10^{5}$ and $1 \times 10^{3}$, followed by an increase at the Bogotá River station. As can be seen in the first part of the irrigation district, the bacteriological quality of the water was better, but the discharge of waste in the municipality of Mosquera deteriorated its quality.

All the samples analyzed in this study and that were collected during the dry season had bacterial indicators, which indicated a microbiological risk. Comparatively, the waters of the Funza-Tres Esquinas Station were within the limits established by the World Health Organization for crop irrigation with raw consumption (fecal coliforms/100 mL $<1000 \mathrm{CFU}$ ).

The microorganism densities found in the Sena, Tibaitatá, Funza and Diamante canals were similar and not very high, implying that, with a not very complex treatment, one or two log units could be reduced to values within the allowed limits.

Although the microbiological quality of the district water was impaired by the discharge of wastewater from Mosquera, it was clear that there is a process of self-purification between this point and the Tobacco station, which can be appreciated by the decrease, on average, of four log units. Unfortunately, this process was reversed by mixing the waters of the irrigation district with the waters of the Bogotá River.

Table 2 shows the results obtained for each microbiological indicator during the sampling period carried out in 2014 and 2015 although these samples were taken during the month of November, which is the rainy season, resulting in a dilution effect for the results. Table 3 shows the results of the physicochemical analyzes performed on the water samples.

The results of Table 2 shown that the coliform contamination stayed the same and, in some cases, even increased as compared to the 2003 data.

The study of coliforms has been accepted worldwide as a reliable parameter since these bacteria are excellent indicators of the presence of enteric pathogenic microorganisms, related to diseases such as cholera, typhoid fever, shigellosis, amebiasis and hepatitis, some of which can survive for long periods in fresh vegetables and survive disinfection processes and even multiply during storage (López et al., 2003). According to the WHO, when there are $1 \times 10^{4}$ thermotolerant coliforms $/ 100 \mathrm{~mL}$, there is an increased risk for diarrheal diseases for consumers in general 
Table 3: Water sample physicochemical analysis results

\begin{tabular}{lllll}
\hline Parameter & 2003 & 2014 & 2015 & Station* \\
\hline $\mathrm{DO}\left(\mathrm{mg} / \mathrm{L} \mathrm{O}_{2}\right)$ & 1.4 & 0.08 & 0.30 & 2 \\
& 0.8 & 0.53 & 0.35 & 3 \\
& 0.7 & 0.36 & 0.12 & 4 \\
& 0.8 & 1.91 & 0.71 & 5 \\
& 1.3 & 0.41 & 0.33 & 6 \\
& 1.2 & 1.26 & 0.40 & 7 \\
$\mathrm{EC}(\mu \mathrm{S} / \mathrm{cm})$ & 0.8 & 1.17 & 0.17 & 8 \\
& 300 & 1237 & 693 & 2 \\
& 380 & 777 & 849 & 3 \\
& 370 & 398 & 1131 & 4 \\
& 380 & 461 & 1506 & 5 \\
& 390 & 444 & 270 & 6 \\
$\mathrm{BOD}{ }_{5}(\mathrm{mg} / \mathrm{L}$ & 800 & 1146 & 430 & 7 \\
$\left.\mathrm{O}_{2}\right)$ & - & 842 & 1140 & 8 \\
& - & 52.20 & 42 & 2 \\
& - & 198 & 261 & 3 \\
& - & 7.50 & 138 & 4 \\
& - & 37.96 & 174 & 5 \\
$\mathrm{COD}(\mathrm{mg} / \mathrm{L}$ & - & 45.60 & 6.06 & 6 \\
$\left.\mathrm{O}_{2}\right)$ & 30 & 35.95 & 90 & 7 \\
& 40 & 439 & 204.80 & 8 \\
& 35 & 29 & 289 & 3 \\
& 45 & 41 & 293 & 4 \\
& 45 & 246 & 71 & 5 \\
& 180 & 226 & 48 & 7 \\
& 300 & 355 & 160 & 8 \\
\hline
\end{tabular}

*2: Ciénaga funza tres esquinas entrance; 3: B-diamante canal; 4: Ciénaga funza exit; 5: Tibaitata canal; 6: Sena canal; 7: San josé canal, mosquera variant; 8: San josé los pinos canal; This study

and for children under 15 years of age in working families (WHO, 2006), as seen in the results for five of the seven sampled stations in 2014 and 2015. On the other hand, the presence of fecal coliforms at loads as high as those observed in the results for the year 2015 gives an indication of the possible presence of pathogenic microorganisms in the water and will potentially be in contact with crops that are being irrigated with this water.

The group of reviewed studies, which the authors of this study participated in Bustos et al. (2004), Ramírez (2007) and Durán et al. (2009) and the studies by Miranda et al. (2008) showed that, in the different sites sampled on the Sabana de Bogotá, the total and fecal coliform values were higher than those allowed by Colombian limits (Decree 1594 of 1984), with values in some samples higher than $1 \times 10^{6}$ for total coliforms and $1 \times 10^{5}$ for fecal coliforms. Based on these results, coliform contamination is the most relevant parameter in terms of water quality, both in the canals and marshes that make up the irrigation district of $\mathrm{La}$ Ramada in the western part of the Sabana de Bogotá as well as in the canals used for irrigation in the municipalities of the central area, covered by the indicated studies. Other studies have confirmed the above conclusion, such as Campos et al. (2015), who studied a farm in this irrigation district, finding that the concentration of fecal coliforms was higher than the WHO guidelines with a health risk for farmers and consumers.
When the physicochemical results obtained for the sites were analyzed, as shown in Table 3, it was observed that, in all of the water samples, the dissolved oxygen content was very low, less than $2.0 \mathrm{mg} / \mathrm{L}$ of $\mathrm{O}_{2}$, which generated anaerobic conditions. These concentrations were related to the high loads of organic matter $\left(\mathrm{BOD}_{5}\right)$ and the variable $\mathrm{COD}$ results and conductivity also showed that there are industrial and urban wastewater discharges, as reported by Torres (2004), who monitored the canals of the irrigation district for unauthorized discharge of domestic and industrial residual water, which was correlated with the results of the microbiological indicators. In addition, Hernández et al. (2015) published the results of an analysis of drug residues in the same 2013 sample sites 2013, which included antibiotics such as clindamycin, clarithromycin and lincomicyn, which generate an additional concern from the point of view of public health since there is a possibility that the bacteria present in the water generate antibiotics resistance.

The study carried out by the Local Development Fondo de Desarrollo Local de Bosa, CORPOICA and DAMA (2001) in the Bosa area, a flood area of the Tunjuelito river watershed on the border between Bogotá and the municipality of Soacha, showed microbiological counts in wastewater used for irrigation, even higher than the studies indicated in the previous paragraph, reaching, in some of the 18 sampling sites, counts of $5.0 \times 10^{8}$ for total coliforms and $3.5 \times 10^{7}$ for fecal coliforms.

The situation described for the Sabana de Bogotá is similar in other places in Colombia and Latin America, where wastewater is used for agricultural irrigation without treatment. Likewise, the use of wastewater without pre-treatment is very common in many places of the world. Farmers often use wastewater because they have no other choice, but also because they have found a source of free fertilizers that achieve better crop yields (Amorós et al., 1989; Silva et al., 2008). Since the studied wastewater, such as those of the Tibanica canal, have a nitrogen content of $50 \mathrm{mg} / \mathrm{L}$ (Jimenez and Martínez, 2005), we estimate that a crop given 4000 $\mathrm{m}^{3} / \mathrm{Ha}$ of irrigation receives a nitrogen dose of 200 $\mathrm{kg} / \mathrm{Ha}$. These amounts can, in many cases, cover the nitrogen requirements of the crop.

In some cases, such as that presented in the municipality of Caqueza, Cundinamarca (Argüello Arias, unpublished), farmers take advantage of the sewage in the upper area, where the sewers of the urban area are located, in order to not incur pumping costs, as well as fertilizers.

The agricultural activity carried out in the outskirts of the town of Caqueza, Cundinamarca is a typical case of the almost exclusive dependence on urban domestic wastewater for crop irrigation. In this area, around 300 Ha of crops, predominantly tomato, paprika, beans and maize, are watered through a system of hoses 


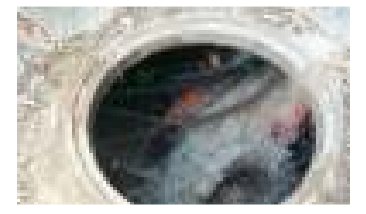

Fig. 1: Hoses catching irrigation water from a sewer in the town center of Caqueza, Cundinamarca (Arguello Arias S.P)

embedded in the main sewers of the sewage system (Fig. 1). There, the farmers have established a system of irrigation that takes advantage of the high slope to carry the wastewater hundreds of meters to the cultivated plots, where the pressure with which the water arrives is able to move dozens of sprinklers that not only cover the soil, but also the totality of the cultivated plants.

As mentioned earlier, the use of sewage is quite widespread in the world. However, most of the wastewater used in agriculture is captured after the water travels significant distances through canals, which play a role similar to that of oxidation ponds, transforming much of the organic matter and, together with the activity of aquatic plants and microorganisms, reducing the pathogen populations. However, the situation described for the municipality of Caqueza is extreme (Argüello Arias, unpublished). There, the wastewater comes directly from the toilets to the crops.

As in many other places where there are situations similar to the one described in the previous paragraph, farmers give little importance to the health hazards of using wastewater. Farmers, on the one hand, value not only the availability of this resource at any time of the year, but also value the contents of nutrients or natural fertilizers that these waters contribute to their crops.

Studies carried out by the CVC (2010) on 10 farms in the RUT irrigation district, Valle del Cauca, Colombia, which captures water from the Cauca River, in the municipalities of Roldanillo and Union, Valle, indicated the presence of total coliforms in a range between $4.30 \times 10^{3}$ and $6.06 \times 10^{5}$ and fecal coliforms had counts between $9.10 \times 10^{2}$ and $1.50 \times 10^{5}$.

According to Lugo-Morin (2009), in Mexico, at the beginning of the 1990s, 150,000 ha depended on irrigation with residual water. At present, that number has increased to over 250,000 ha and this practice is found in the States of Hidalgo, Michoacán, San Luis Potosí, Morelos, Nayarit, Colima, Puebla, Tlaxcala, Estado de México, Sonora, Chihuahua and Ciudad de Mexico.

Álvarez et al. (2008) carried out a study on the quality of wastewater used for agricultural irrigation. The study area was located in the Zacualtipan, Pachuca and Tulancingo Rural Development Districts of the State of Hidalgo, found in the upper basin of the Panuco River. The concentration of fecal coliforms (NMP) ranged from $1.07 \times 10^{3} / 100 \mathrm{~mL}$, up to the Estanzuela Dam, to $2.4 \times 10^{4} / 100 / \mathrm{mL}$, in the Tulancingo River, where the water was highly contaminated, which exceeded, up to 12 times in order of magnitude, the
LMP established by the Mexican limit (1000 to 2000 NMP 100/mL).

\section{CONCLUSION}

With these results, it was concluded that the surface water that is being used for crop irrigation has high loads of microorganisms, such as total and fecal coliforms, from the residual water that is discharged into bodies of water without any treatment, which generates a potential risk to the health of the consumers of fresh vegetables, not only because of the presence of the evaluated microorganisms, but also because of intestinal pathogenic microorganisms.

\section{ACKNOWLEDGMENT}

The authors thank the Bogota Research Division of the National University of Colombia, DIEB, for the financing provided through project code 37518 and microbiologist Keile Bruges and engineers Pablo Cubides and Jose R. Vargas for their help with the sampling and analysis.

\section{CONFLICT OF INTEREST}

The authors declare no conflict of interest.

\section{REFERENCES}

Acevedo, L., C. Mendoza and R. Oyón, 2001. Coliformes totales, fecales y algunas enterobacterias, Sthaphylococcussp. y hongos en ensaladas para perro calientes expendidas en la ciudad de Maracay, Venezuela. ALAN, 51(4).

Allende, A. and J. Monaghan, 2015. Irrigation wáter quality for leafy crops: A perspective of risks and potential solutions. Int. J. Environ. Res. Public Health, 12(7): 7457-7477.

Álvarez, J.P.A., J.E.R. Panta, C. Ayala and E.H. Acosta, 2008. Calidad Integral del Agua Superficial en la Cuenca Hidrológica del río Amajac. Inf. Tecnol., 19(6): 21-32.

Amorós, I., J.L. Alonso and I. Peris, 1989. Study of microbial quality and toxicity of effluents from two treatment plants used for irrigation. Water Sci. Tech., 21(3): 243-246.

APHA, 2012. Standard Methods for the Examination of Water and Waste Water. 22nd Edn., American Public Health Association, Washington, DC.

Bustos, L.M.C., H. Arguello Arias, B.M.C. Diaz and A.J.M. Ortiz, 2004. Resumen Ejecutivo Componente 1: Tratamiento de Aguas. Convenio Universidad Nacional-SENA. SENA, Programa Integral de Transferencia de Tecnología para la Producción Limpia y Comercialización de Hortalizas en la Sabana de Bogotá. Bogotá, pp: 60. 
Campos, C., A.M. Contreras and F.R. Leiva, 2015. Evaluación del riesgo sanitario en un cultivo de lechuga (Lactuca sativa) debido al riego con aguas residuales sin tratar en el Centro Agropecuario Marengo (Cundinamarca, Colombia). Rev. Biosalud, 14(1): 69-78.

CAR, 2007. Evaluación Ambiental y el Plan de Gestión Ambiental-EA del proyecto de Adecuación Hidráulica y Recuperación Ambiental del río Bogotá, 1: 192.

Castro-Ibáñez, I., M.I. Gil, J.A. Tudela, R. Ivanek and A. Allende, 2015. Assessment of microbial risk factors and impact of meteorological conditions during production of baby spinach in the Southeast of Spain. Food Microbiol., 49: 173-181.

CVC, 2010. Calidad microbiológica del agua en 10 muestras del distrito de riego RUT, Roldanillo, Valle del Cauca. Informe Técnico. Dirección Ambiental, pp: 10.

Durán, Z., C.J. Collazos and H. Argüello Arias, 2009. Evaluación de un Sistema de Lagunas para el Tratamiento y Reuso de Aguas Residuales en el Riego de Cultivos de Hortalizas. Resumenes VI Congresso Brasileiro de Agroecologia, II CongressoLatinoamericano de Agroecologia 9 a 12 de novembro 2009, Curitiba-PR/Brasil. Rev. Bras. Agroecol., 4(2): 1395-1399.

Fondo de Desarrollo Local de Bosa, CORPOICA and DAMA, 2001. Asistencia Técnica Agropecuaria a pequeños Agricultores de Bosa. Convenio Especial de Cooperación Técnica y Científica 045. Informe Final, pp: 120.

Fonseca, J.A., R.D. Heredia, C. Ortiz, M. Mazo, C.A. Clavijo-Ramirez and M.C. Lopez, 2016. Identification of Entamoeba moshkovskii in treated waste water used for agriculture. EcoHealth, 13(1): 156-160.

Hernández, F., M., Ibañez, A.M. Botero-Coy, R. Bade, M.C. Bustos-López et al., 2015. LC-QTOF MS screening of more than 1,000 licit and illicit drugs and their metabolites in wastewater and surface waters from the area of Bogotá, Colombia. Anal. Bioanal. Chem., 407: 6405-6416.
Holvoet, K., I. Sampers, M. Seynnaeve, L. Jacxsens and M. Uyttendaele, 2015. Agricultural and management practices and bacterial contamination in greenhouse versus open field lettuce production. Int. J. Env. Res. Pub. He., 12: 32-63.

Jimenez, J. and G. Martinez, 2005. Evaluación de la calidad del agua residual utilizada para riego de hortalizas en el canal Tibanica Soacha (Cundinamarca). Tesis Ingeniería Civil, Universidad Nacional De Colombia - Sede Bogotá, pp: 143.

López, V.L., R.J. Romero and F.F. Duarte, 2003. Calidad microbiológica y efecto del lavado y desinfección en vegetales pretrozados expendidos en Chile. Arch. Latinoam. Nutr., 53(4): 383-388.

Lugo-Morin, D.R., 2009. El uso de aguas residuales en la agricultura en México. Ambiente y Desarrollo. Bogotá (Colombia), XIII(24): 9-28.

Miranda, D., C. Carranza and G. Fischer, 2008. Calidad de água de riego en la Sabana de Bogotá. 1st Edn., Universidad Nacional de Colombia, Facultad de Agronomía, Bogotá.

Pachepsky, Y., D.R. Shelton, J.E.T. McLain, J. Patel and R.E. Mandrell, 2011. Irrigation waters as a source of pathogenic microorganisms in produce. A review. Adv. Agron., 113: 73-138.

Ramírez, A., 2007. Tratamiento y reuso de las aguas residuales del canal Tibanica para el riego de cultivos mediante un sistema de lagunas. Tesis de Maestría. Universidad Nacional de Colombia., Bogotá.

Silva, J., P. Torres and C. Madera, 2008. Domestic wastewater reuse in agriculture. A review. Agron. Colombiana, 26(2): 347-359.

Steele, M. and J. Odumeru, 2004. Irrigation water as source of foodborne pathogens on fruit and vegetables. J. Food Protect., 67(12): 2839-2849.

Torres, L., 2004. Evaluación de la Incidencia del Vertido de Aguas Residuales Urbanas en el Distrito de Riego La Ramada. Trabajo de Grado, Universidad Nacional de Colombia, Bogotá.

WHO, 2006. WHO Guidelines for the Safe Use of Wastewater, Excreta and Greywater. UNEP, France, Vol. 2. 